\title{
KONSISTENSI PRODUKSI NATA DALAM MEDIA FERMENTASI YANG MENGANDUNG HIDROLISAT UBI KAYU
}

\section{CONSISTENCY OF NATA PRODUCTION IN FERMENTATION MEDIUM CONTAINING CASSAVA HYDROLYSATE}

\author{
Lutfansyah Muchtar, Nisa Rachmania Mubarik, dan Antonius Suwanto*) \\ Departemen Biologi, Fakultas Matematika dan Ilmu Pengetahuan Alam, Institut Pertanian Bogor \\ Jl. Agatis, Kampus IPB Dramaga, Bogor, 16680, Indonesia \\ E-mail: asuwanto@indo.net.id
}

Makalah: Diterima 26 Oktober 2016; Diperbaiki 1 Agustus 2017; Disetujui 7 Agustus 2017

\begin{abstract}
Nata de coco is known as a gelatinous substance, white to creamy-yellow, firm, glossy and not sticky, produced by some bacteria, which forms on the surface of coconut water medium during fermentation. Acetobacter xylinum (current name: Gluconacetobacter xylinus) is the common bacteria which synthesized nata de coco. Besides coconut water, there are some alternatives for making nata, such as cassava. Gluconacetobacter sp. was employed in this study to produce nata de coco from cassava hydrolysate medium $(U)$ and compared it qualitatively and quantitatively to coconut water medium $(K)$. In U medium, glucose was the main product derived from hydrolysis of cassava. Fermentation was conducted three times with each former fermentations became sources of inocula for the next fermentations, respectively. All data were analysed with IBM SPSS Statistics 23. Fermentation product of nata from U medium were relatively stable in thickness, wet weight, dry weight, yield, water content, and log from total bacteria (quantitative) and in colour, texture, transparency, and surface of nata (qualitative). Glucose was rapidly consumed by bacteria then other sugar (fructose and sucrose). Glucose consumption and nata yield was affected by the number of bacteria. However, nata yield was not significantly influenced by glucose consumption. Nata yield was possibly influenced by other factors such as nutrient content in U medium. Growth dynamics of Gluconacetobacter sp. was measured in log cfu $\mathrm{mL}^{-1}$ on Hassid-Barker Agar (HBA) medium and relative number of $16 S$ rRNA genes. Bacterial growth during fermentation in $U$ medium were relatively more stable than fermentation on $K$ medium although the yield in $K$ medium gradually increased and were higher than U medium.
\end{abstract}

Keywords: cassava hydrolysate, Gluconacetobacter sp., nata, stable fermentation

\section{ABSTRAK}

Nata de coco dikenal sebagai substansi menyerupai agar-agar, berwarna putih hingga krem kekuningan, kokoh, mengkilap, dan tidak lengket, diproduksi oleh beberapa bakteria, yang terbentuk di atas media air kelapa selama fermentasi. Acetobacter xylinum (nama sekarang: Gluconacetobacter xylinus) adalah bakteri yang umum digunakan untuk mensintesis nata de coco. Selain air kelapa terdapat beberapa alternatif untuk membuat nata, seperti ubi kayu. Gluconacetobacter sp. digunakan pada penelitian ini untuk produksi nata dari media hidrolisat ubi kayu (U) dan dibandingkan secara kualitatif dan kuantitatif dengan media air kelapa (K). Pada media $\mathrm{U}$, glukosa adalah produk utama yang berasal dari hidrolisis ubi kayu. Fermentasi dilakukan tiga kali dengan menggunakan inokulum dari fermentasi sebelumnya. Semua data dianalisis dengan IBM SPSS Statistics 23. Produk fermentasi nata media U relatif lebih stabil dilihat dari ketebalan, bobot basah, bobot kering, yield, kadar air dan log dari total bakteri (kualitatif) dan stabil pada warna, tekstur, transparansi, dan permukaan nata. Glukosa lebih cepat dikonsumsi oleh bakteri daripada gula lainnya (fruktosa and sukrosa). Konsumsi glukosa dan yield nata dipengaruhi oleh jumlah bakteri. Akan tetapi yield nata tidak dipengaruhi signifikan oleh konsumsi glukosa. Yield nata dapat dipengaruhi oleh faktor lain seperti nutrisi yang terdapat pada media U. Dinamika pertumbuhan Gluconacetobacter sp. diperlihatkan dalam log cfu mL $\mathrm{m}^{-1}$ pada media Hassid-Barker Agar (HBA) dan jumlah relatif gen $16 \mathrm{~S}$ rRNA. Pertumbuhan bakteri selama fermentasi pada media U relatif lebih stabil dari fermentasi media $\mathrm{K}$ meskipun yield pada media $\mathrm{K}$ meningkat secara bertahap dan menjadi lebih besar dari yield fermentasi pada media $\mathrm{U}$.

Kata kunci: Gluconacetobacter sp., nata, hidrolisat ubi kayu, fermentasi yang stabil

\section{PENDAHULUAN}

Nata de coco adalah produk fermentasi dengan air kelapa sebagai sumber nutrisinya (Almeida, 2013). Nata de coco merupakan hasil industri selulosa bakteri terbesar di Indonesia berbasis kelapa yang sudah menembus pasar ekspor (Niramas, 2012). Bakteri penghasil nata Gluconacetobacter xylinus (Acetobacter xylinum) adalah bakteri dari keluarga Acetobacteraceae yang 
termasuk dalam genus Gluconacetobacter (Yamada dan Yukphan, 2008).

Isolat A. xylinum selain dapat tumbuh pada media kelapa dapat pula tumbuh pada berbagai media seperti pada buah-buahan baik jus buah atau limbah buah (Kurosumi et al., 2009; Nazir, 2012; Zakaria dan Nazeri, 2012; Afreen dan Lokeshappa, 2014). Limbah tapioka dapat juga dijadikan sebagai media tumbuh (Naufalin dan Wibowo, 2004; Soebrata et al., 2012). Salah satu media fermentasi nata de coco yang potensial ialah hidrolisat ubi kayu yang dapat menggantikan sumber nutrisi dari kelapa, karena kadar proksimat, vitamin dan mineral pada ubi kayu memiliki banyak kesamaan dengan air kelapa (USDA, 2016). Hidrolisat ubi kayu dibuat dengan proses hidrolisis baik menggunakan enzim dan atau asam sehingga menjadi hidrolisat berupa glukosa (Collares et al., 2012; Ayoola et al., 2013). Pada penelitian terdahulu, penggunaan hidrolisat ubi kayu sebagai media sumber karbon berupa glukosa pada produk dilakukan pada fermentasi bioetanol (Arnata, 2009; Juara, 2011; Maharani, 2011; Ruiz et al., 2011; Collares et al., 2012).

Glukosa merupakan sumber karbon penghasil yield terbesar setelah gliserol pada fermentasi nata oleh A. xylinum (Keshk dan Sameshima, 2005). Selain glukosa, penambahan nutrisi seperti asam asetat sebagai sumber karbon dan pengatur $\mathrm{pH}$, amonium sulfat sebagai sumber nitrogen dan sulfur dapat meningkatkan produk akhir selulosa (Jagannath et al., 2008; Lestari et al., 2014). Son et al. (2003) mengungkapkan bahwa penambahan senyawa pada media sintetis beberapa diantaranya glukosa $1,5 \%, \quad\left(\mathrm{NH}_{4}\right)_{2} \mathrm{SO}_{4} \quad 0,2 \%$, $\mathrm{KH}_{2} \mathrm{PO}_{4} 0,3 \%, \mathrm{MgSO}_{4} \cdot 7 \mathrm{H}_{2} \mathrm{O} 0,08 \%$, nikotinamida $0,00005 \%$, menghasilkan selulosa maksimal sebesar 4,16 $\mathrm{gL}^{-1}$ setelah fermentasi selama 8 hari dan kondisi $200 \mathrm{rpm}$. Vitamin C (asam askorbat) 0,5\% dapat meningkatkan produksi fermentasi nata menjadi 1,9 kali lebih banyak daripada tanpa vitamin C (Keshk, 2014).

Selain nutrisi, mikrob yang terlibat dalam fermentasi dapat berpengaruh terhadap produksi nata. Menurut Seumahu et al. (2007) pada proses fermentasi tradisional ternyata dapat melibatkan banyak jenis bakteri yang kualitasnya dapat dipantau dengan melihat profil Amplified Ribosomal DNA Restriction Analysis (ARDRA) komunitas bakteri selama fermentasi Nata de coco. Dinamika yang terjadi pada komunitas bakteri dapat berpengaruh positif terhadap hasil fermentasi seperti pada tempe (Barus, 2008; Efriwati, 2013; Seumahu et al., 2013), susu dan keju (Neviani et al., 2013). Kombinasi kondisi optimum dan dinamika komunitas bakteri dapat digunakan sebagai dasar pertimbangan bagi pengembangan industri yang memproduksi selulosa dengan produktifitas dan stabilitas yang tinggi. Tujuan dari penelitian ini adalah (1) mempelajari penggunaan hidrolisat ubi kayu sebagai sumber nutrisi alternatif fermentasi nata termasuk dinamika pertumbuhan bakterinya, dan (2) Mengamati konsistensi produksi nata yang dilihat dari stabilitas variabel kuantitatif yang diukur.

\section{BAHAN DAN METODE}

\section{Bahan}

Bahan utama penelitian ini adalah ubi kayu berusia tanam minimal 9 bulan yang didapatkan dari pasar tradisional Sukabumi untuk bahan baku pembuatan hidrolisat. Bahan lain yang digunakan adalah air kelapa untuk pembuatan media fermentasi pembanding. Bakteri yang digunakan untuk pembuatan inokulum fermentasi nata adalah Gluconacetobacter sp. yang berumur sekitar 4 hingga 7 hari yang didapatkan dari PT Niramas Utama.

\section{Metode}

\section{Penyiapan Media Fermentasi Nata}

Proses pembuatan media fermentasi dimulai dengan hidrolisis ubi kayu untuk membuat sediaan hidrolisat yang homogen. Ubi kayu dibersihkan kulitnya, sebanyak $1000 \mathrm{~g}$ dipotong kemudian ditambahkan air (1:1) (Johnson et al., 2009). Ubi kayu dihaluskan (Zeppelin Blender Super Quality CB7600-C3) selama 3 menit dengan kecepatan maksimal. Penentuan dosis enzim ditentukan berdasarkan kadar pati teoritis dari ubi kayu segar berkisar antara 27\% hingga 37\% (Lebot, 2009; Collares et al., 2012). Pada penelitian ini digunakan perkiraan kadar pati $30 \%$, sedangkan untuk mengetahui perkiraan kadar glukosa untuk menghitung jumlah enzim yang digunakan didapat dari kadar pati $(\mathrm{g} / 100 \mathrm{~g})$ / 0,9 (Li, 2006). Untuk mengatur $\mathrm{pH}$ hidrolisis dilakukan penambahan $\mathrm{HCl}$ 0,1 mol L-1 (Collares et al., 2012). Enzim pertama yang digunakan untuk proses likuifikasi ialah $\alpha$ amilase Liquozyme ${ }^{\circledR}$ Supra (Novozyme) yang aktivitasnya $135 \mathrm{KNU} / \mathrm{g}$ (Kilo Novo Unit/g) dan diaplikasikan pada $\mathrm{pH}$ rendah $(5,2-5,6)$, suhu 90 $95^{\circ} \mathrm{C}$ selama 90 menit (Słomińska et al., 2013). Dosis enzim yang digunakan untuk likuifikasi adalah $0,127 \mathrm{KNU} / \mathrm{g}$ pati dalam keadaan kering padat. Enzim kedua yang digunakan untuk proses sakarifikasi adalah Dextrozyme DX (Novozyme) yang aktivitasnya $24904 \mathrm{U} \mathrm{mL}^{-1}$ pada suhu $61^{\circ} \mathrm{C}$ dan pH 5 (Sunaryanto et al., 2013). Dosis enzim yang digunakan untuk sakarifikasi adalah 69 U/ g pati dalam keadaan kering padat. Total waktu hidrolisis adalah tiga jam (Collares et al., 2012). Hasil hidrolisis berupa hidrolisat dipisahkan dari seratnya dengan membran filter nilon mesh 100. Hidrolisat kemudian diukur brix-nya dengan refractometer (AOAC, 1990).

Media hidrolisat ubi kayu (U) dibuat dengan mengencerkan hidrolisat hingga brix-nya menjadi $5 \%$ (sesuai dengan uji pendahuluan), kemudian dilakukan penambahan ammonium sulfat sebanyak 0,5\% (Jagannath et al., 2008). Asam asetat 
ditambahkan hingga $\mathrm{pH}$ 3,5 (kondisi fermentasi di PT Niramas Utama). Media air kelapa $(\mathrm{K})$ dibuat dengan penambahan sukrosa hingga brix totalnya menjadi 5\% dengan penambahan bahan lain yang sama dengan media U. Setiap media dituangkan 30 $\mathrm{mL}$ ke dalam botol vial $60 \mathrm{~mL}$ dan disterilisasi selama 15 menit, tekanan $15 \mathrm{psi}$, suhu $121^{\circ} \mathrm{C}$.

\section{Pembuatan Inokulum dan Fermentasi Nata}

Koloni Gluconacetobacter sp. yang tumbuh pada media CWA digunakan sebagai inokulum awal dengan menambahkan 12 koloni setiap $30 \mathrm{~mL}$ media fermentasi $U$ dan K. Fermentasi inokulum berlangsung selama 8 hari pada suhu $30{ }^{\circ} \mathrm{C}$. Inokulum awal dengan produk nata yang ketebalannya di atas $10 \mathrm{~mm}$ digunakan sebagai inokulum pada fermentasi pertama, pemilihan ketebalan nata mengikuti Jagannath et al. (2008) yang memanen nata saat ketebalannya mencapai 8$10 \mathrm{~mm}$.

Fermentasi pada penelitian ini terdiri dari atas tiga kelompok fermentasi yaitu fermentasi pertama (F1), kedua (F2) dan ketiga (F3) dengan penggunaan inokulum yang berasal dari fermentasi sebelumnya. Inokulum yang ditambahkan pada setiap fermentasi (F1, F2, dan F3) adalah sebanyak $10 \%$ (v/v) (Zakaria dan Nazeri, 2012). Fermentasi pada F1, F2, dan F3 dilakukan selama 8 hari dalam (Hungund dan Gupta, 2010). Suhu fermentasi $30^{\circ} \mathrm{C}$ pada kondisi statis (Jagannath et al., 2008; Hungund dan Gupta, 2010).

\section{Pengamatan Variabel Kualitatif Nata}

Pengamatan kualitatif dilakukan

berdasarkan karakteristik kualitas nata secara fisik berdasarkan National Cottage Industry Development Authority (NADICA) diantaranya: bentuk menyerupai agar-agar, putih krem, dan kokoh, tidak cenderung pecah saat diangkat, mengkilap, tidak lengket, translucent (tembus cahaya) (Sanchez, 2008). Pada penelitian ini, variabel yang diamati antara lain: warna, transparansi, tekstur, dan permukaan nata. Variabel pengukuran diamati dengan pemberian Numerical Scor, skor dengan skala 1 (satu) hingga 3 (tiga) (Dawson dan Harris, 1951). Nata yang mendekati karakteritik nata berkualitas diberi skor 3, untuk variabel warna skala yang diamati kecoklatan, krem, hingga putih atau putih sedikit krem, untuk variabel transparansi diamati kekeruhannya, dilihat dari keruh, sedikit transparan hingga translucent, untuk tekstur dapat dirasakan dengan menyentuh dan sedikit menekan nata apakah lembek, lembek tetapi bentuk teratur atau kokoh, dan permukaan nata dapat dirasakan dengan menyentuh nata apakah kasar, kasar sebagian atau halus.

\section{Pengukuran dan Perhitungan Variabel Kuantitatif Nata}

Nata de coco hasil fermentasi media U dan media $\mathrm{K}$ dipanen, kemudian diukur ketebalannya, lalu dicuci dengan air beberapa kali untuk menghilangkan asam asetat, sesudah itu direndam selama 24 jam mengikuti Jagannath et al. (2008). Nata hasil perendaman ditiriskan sekitar satu menit di atas kertas saring, kemudian diukur bobot basahnya. Nata kemudian diperas airnya sebelum pengukuran bobot kering. Jagannath et al. (2008) menggunakan suhu pengeringan $75^{\circ} \mathrm{C}$, kemudian bobot basah dan kering digunakan untuk perhitungan kadar air.

Kadar gula pada awal dan akhir fermentasi dapat menentukan preferensi jenis gula yang digunakan mikrob selama fermentasi nata. Kadar gula diukur dengan High Performance Liquid Chromatography (HPLC) (Zhong et al., 2013). HPLC yang digunakan adalah Shimadzu LC-10AD dan RID 10A. Sampel cairan pada awal dan akhir fermentasi (F1, F2, dan F3) sebanyak $1 \mathrm{~mL}$ diencerkan hingga 10 kalinya dengan aquadest, kemudian disaring dengan kertas saring (Whatman No. 1). Filtrat yang dihasilkan disaring kembali dengan syringe filter steril berukuran $0,2 \mu \mathrm{m}$ kemudian diinjeksikan ke dalam HPLC dan dilewatkan pada column Shimadzu Shim-pack SCR$101 \mathrm{P}$ dengan laju alir $1 \mathrm{~mL} / \mathrm{menit}$ pada suhu $60^{\circ} \mathrm{C}$. Aquabidest steril yang telah disonikasi yang digunakan sebagai fase geraknya merupakan modifikasi dari penggunaan ultrapure water (Farid et al., 2015). Konsumsi glukosa, yield dan konversi glukosa menjadi nata dihitung mengikuti Lestari et al. (2014).

Dinamika pertumbuhan Gluconacetobacter sp. dapat diamati dari jumlah sel bakteri yang dilakukan dengan mengambil $1 \mathrm{~mL}$ sampel cairan dari hasil fermentasi inokulum awal dan hasil fermentasi media U dan K (F1, F2, F3) pada hari ke8, kemudian diencerkan dengan $9 \mathrm{~mL} \mathrm{NaCl} 0,85 \%$ dan disebar pada media agar-agar Hassid Barker (HBA) sebanyak 0,1 mL (Seumahu et al., 2007). Sampel diinkubasi pada suhu $30^{\circ} \mathrm{C}$ selama 7 hari kemudian jumlah koloni diamati dan dihitung pada pengenceran $10^{-3}$.

\section{Perbandingan Konsistensi Produk Fermentasi dan Pengaruh Beberapa Variabel Pengukuran Terhadap Yield Nata}

Untuk melihat konsistensi media $\mathrm{U}$ dan $\mathrm{K}$ pada F1, F2, dan F3 dilakukan pengujian statistik variabel kualitatif dan kuantitatif : ketebalan nata, bobot basah dan bobot kering nata, yield, kadar air, log jumlah koloni mikrob pada akhir fermentasi, penggunaan gula selama fermentasi. Selain itu juga dilihat pengaruh jumlah koloni bakteri terhadap konsumsi glukosa dan yield nata serta pengaruh konsumsi glukosa dan konversi glukosa menjadi nata terhadap yield nata. Data pengukuran diolah dengan analisis variansi, uji Kruskal-Wallis, dan uji regresi sederhana (Pearson) pada taraf 5\% (IBM SPSS Statistics 23). 


\section{HASIL DAN PEMBAHASAN}

\section{Inokulum Nata}

Hasil fermentasi inokulum nata yang berasal dari media $\mathrm{U}$ dan $\mathrm{K}$ yang ditambahkan koloni Gluconacetobacter sp. menunjukkan hasil yang terlihat berbeda produk natanya (Gambar 1). Inokulum untuk F1 untuk fermentasi media $\mathrm{U}$ dan media $\mathrm{K}$ menggunakan inokulum yang berasal dari media U (Gambar 1A).

Inokulum media $\mathrm{U}$ tersebut memiliki rerata tebal nata $11,10 \mathrm{~mm}$, bobot basah $8,66 \mathrm{~g}$, bobot kering $0,096 \mathrm{~g}$, kadar air $98,88 \%$, yield $3,428 \mathrm{gL}^{-1}$ dan $\log$ jumlah koloni $5,359 \mathrm{cfu} \mathrm{mL}^{-1}$. Inokulum media $\mathrm{K}$ tidak membentuk nata pada kondisi fermentasi yang sama dengan inokulum media U sehingga tidak digunakan untuk fermentasi berikutnya (Gambar 1B).

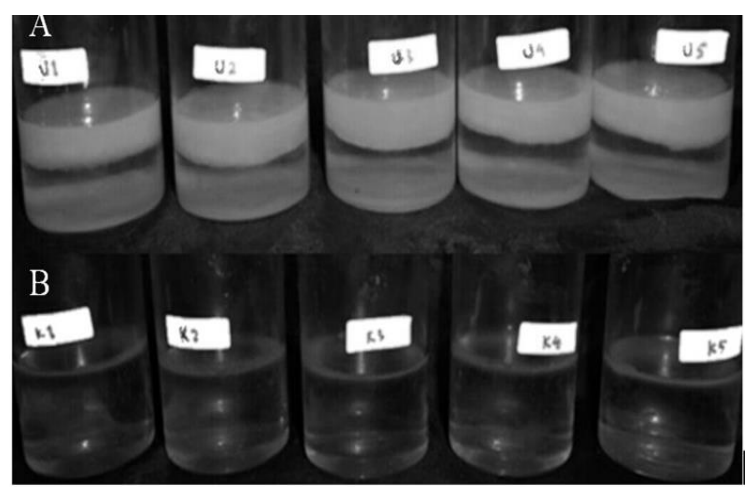

Gambar 1. Inokulum yang berasal dari koloni Gluconacetobacter sp. (A) media hidrolisat ubi kayu (U), (B) media air kelapa (K)

Perbedaan hasil akhir inokulum pada media $\mathrm{U}$ dan $\mathrm{K}$ dapat disebabkan karena adanya perbedaan komposisi gula pada masing-masing yang berinteraksi dengan komponen lain seperti asam asetat. Menurut Toda et al. (1997) penambahan 20 $\mathrm{gL}^{-1}$ asam asetat pada media yang mengandung glukosa dapat meningkatkan produksi selulosa 4 kali daripada kondisi fermentasi statis oleh A. xylinum galur DA.

\section{Konsistensi Produk Fermentasi Nata}

Hasil fermentasi nata pada media $U$ dan media $\mathrm{K}$ selama $\mathrm{F} 1$, F2, dan F3 ditunjukkan pada Gambar 2. Konsistensi produk fermentasi nata pada media $\mathrm{U}$ dan media $\mathrm{K}$ dapat dilihat dari variabel kualitatif dan kuantitatif yang diamati pada F1, F2, dan F3. Hasil pengamatan secara kualitatif nata ditunjukkan dengan frekuensi skor (Gambar 3).

Hasil pengamatan secara kualitatif nata ditunjukkan dengan frekuensi skor (Gambar 3). Gambar 3A menunjukkan frekuensi skor warna nata, Gambar 3B menunjukkan frekuensi skor tekstur nata, Gambar 3C menunjukkan frekuensi skor transparansi nata, dan Gambar 3D menunjukkan frekuensi skor permukaan nata, pada media $\mathrm{U}$ dan media K. Pemberian skor skala 3 mengikuti penilaian terhadap kualitas yang menunjukkan baik, intermediet, dan kurang baik (Dawson dan Harris, 1951).

Berdasarkan hasil pengamatan kualitatif warna memperlihatkan tidak adanya perbedaan kualitas antara nata pada media $\mathrm{U}$ dan media $\mathrm{K}$ yang memiliki warna putih krem (skor 3). Pada nata dari media U pada F1, F2, dan F3 memiliki skor tekstur, transparansi dan permukaan nata 2 yang artinya berada diantara nata berkualitas baik dan kurang baik (intermediet). Pada nata media $\mathrm{K}$ tekstur nata dari F1 hingga F3 cenderung lembek, hasil pengamatan transparansi menunjukkan hasil yang transparan pada nata F1 dan F2 dikarenakan tipis, sedangkan pada F3 sudah mengalami perbaikan kualitas. Permukaan nata pada media $\mathrm{K}$ untuk F1 dan F2 memiliki permukaan yang cenderung tidak rata tetapi mengalami perbaikan yang cukup signifikan pada F3.

Produk nata pada media U dan K (Gambar 2 dan Gambar 3) belum memenuhi semua kriteria nata yang baik berdasarkan NADICA yang memiliki ciri bentuknya menyerupai agar-agar, putih krem, dan kokoh, tidak cenderung pecah saat diangkat, mengkilap, tidak lengket, dan translucent (tembus cahaya) (Sanchez, 2008). Menurut Jagannath et al. (2008) produksi nata de coco dipengaruhi oleh $\mathrm{pH}$, sukrosa dan amonium sulfat, apabila kombinasi antara ketiga faktor tersebut tidak sesuai maka akan menghasilkan nata dengan kualitas buruk. Nilai $\mathrm{pH}$ sekitar 3,5 menghasilkan nata yang tipis pada media air kelapa yang mengandung sukrosa.

Produk nata pada media U dan K (Gambar 2 dan Gambar 3) belum memenuhi semua kriteria nata yang baik berdasarkan NADICA yang memiliki ciri bentuknya menyerupai agar-agar, putih krem, dan kokoh, tidak cenderung pecah saat diangkat, mengkilap, tidak lengket, dan translucent (tembus cahaya) (Sanchez, 2008). Menurut Jagannath et al. (2008) produksi nata de coco dipengaruhi oleh $\mathrm{pH}$, sukrosa dan amonium sulfat, apabila kombinasi antara ketiga faktor tersebut tidak sesuai maka akan menghasilkan nata dengan kualitas buruk. Nilai $\mathrm{pH}$ sekitar 3.5 menghasilkan nata yang tipis pada media air kelapa yang mengandung sukrosa.

Pola perubahan rataan variabel kuantitatif disajikan pada Gambar 4. Pada fermentasi media $U$ menghasilkan rataan tebal nata 9,7-11,0 mm, bobot basah 8,294-9,040 g, bobot kering 0,090- 0,114 g, yield 28,57-34,76 $\mathrm{gL}^{-1}$, kadar air nata 98,621$98,935 \%$ dan $\log$ jumlah koloni bakteri $\times 6,153-$ $6,299 \mathrm{cfu} \mathrm{mL}^{-1}$. Hasil pengukuran fermentasi media $\mathrm{K}$ memiliki rataan tebal nata $1,0-12,0 \mathrm{~mm}$, bobot basah 0,852-10,294 g, bobot kering 0,026- 0,130 g, yield 8,25-41,27 $\mathrm{gL}^{-1}$, kadar air nata 96,523-98,737 $\%$ dan log jumlah koloni bakteri 6,009-6,327 cfu $\mathrm{mL}^{-1}$. 
Berdasarkan hasil pengujian anava satu jalur menunjukkan tidak terdapat perbedaan yang signifikan pada rataan variabel pengukuran F1, F2 dan F3 pada taraf 5\%. Pada fermentasi media K terdapat perbedaan bobot kering, bobot basah, kadar air, ketebalan, yield nata de coco dan log jumlah koloni bakteri (uji Kruskal-Wallis) antara fermentasi $\mathrm{F} 1, \mathrm{~F} 2$ dan $\mathrm{F} 3$ pada taraf $5 \%$.
F1

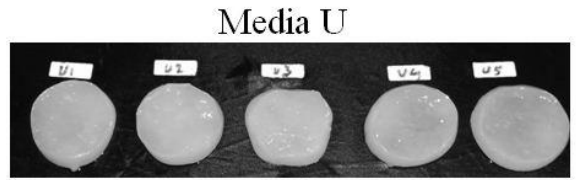

F2

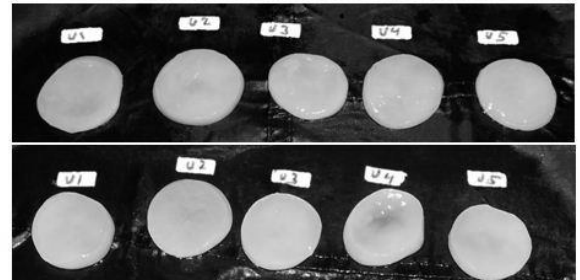

Media K

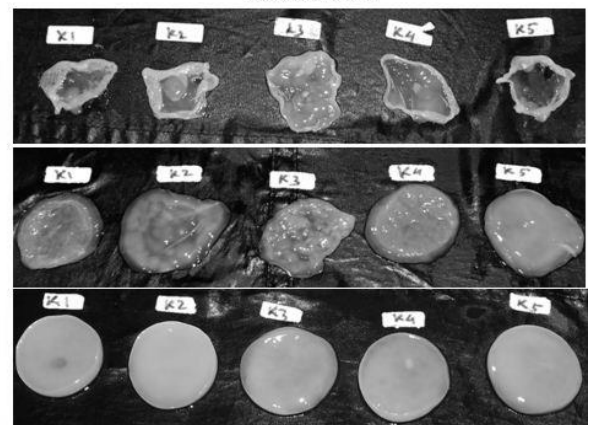

Gambar 2. Nata hasil fermentasi 1 (F1), fermentasi 2 (F2), dan fermentasi 3 (F3) pada media ubi kayu (U) dan media air kelapa $(\mathrm{K})$

A

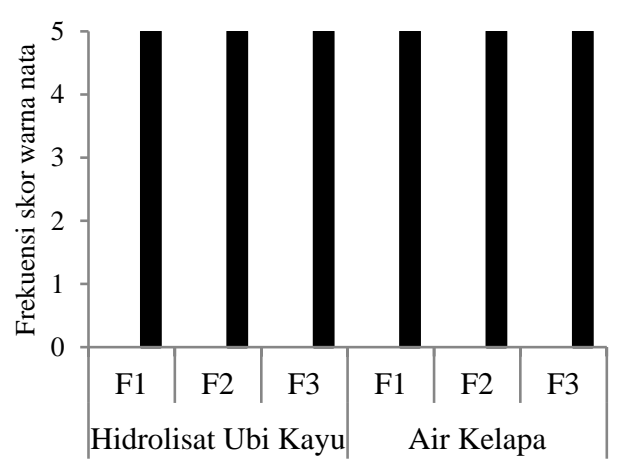

Fermentasi Nata

$\mathrm{C}$

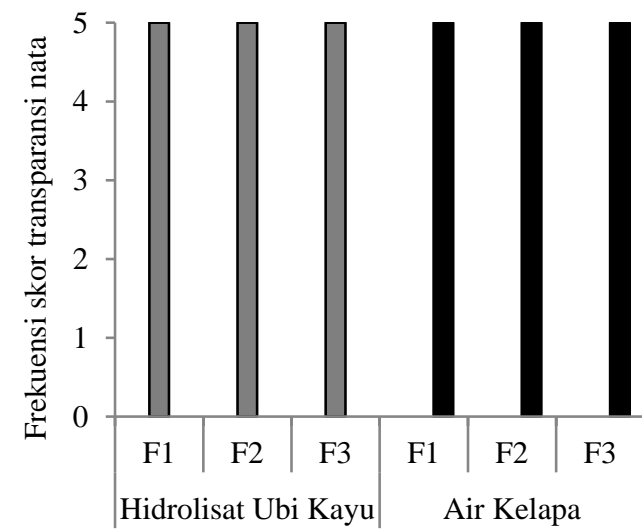

Fermentasi Nata
B

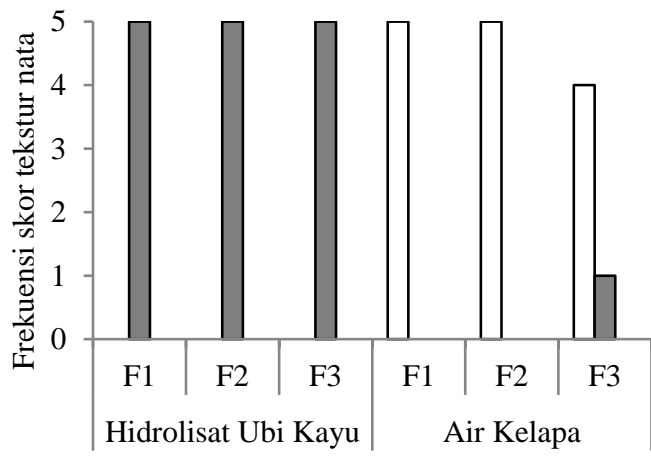

Fermentasi Nata

$\mathrm{D}$

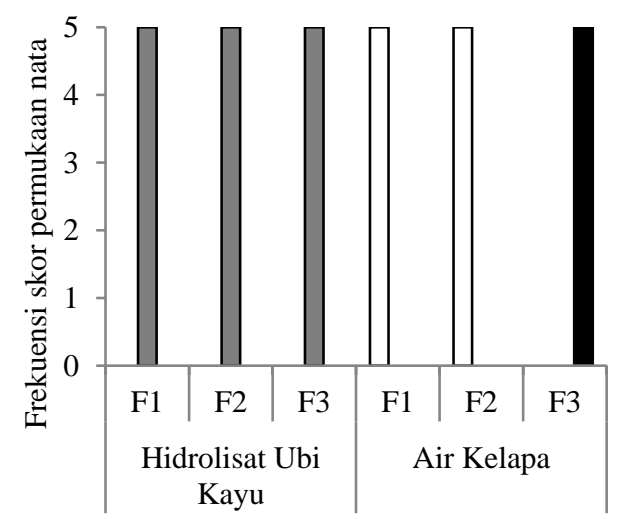

Fermentasi Nata

\section{$\square$ Skor $1 \square$ Skor $2 \square$ Skor 3}

Gambar 3. Frekuensi skor pengamatan kualitatif nata (A) warna, (B) tekstur, (C) transparansi, dan (D) permukaan pada media hidrolisat ubi kayu (U ) dan media air kelapa (K) selama fermentasi $1(\mathrm{~F} 1)$, fermentasi 2 (F2), dan fermentasi 3 (F3) 
A

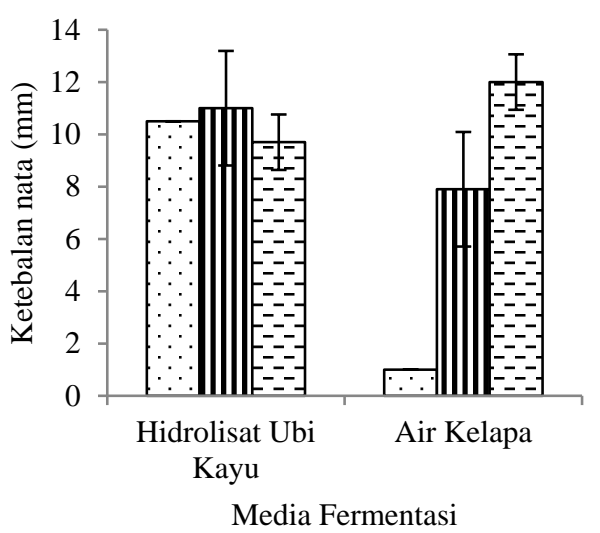

C

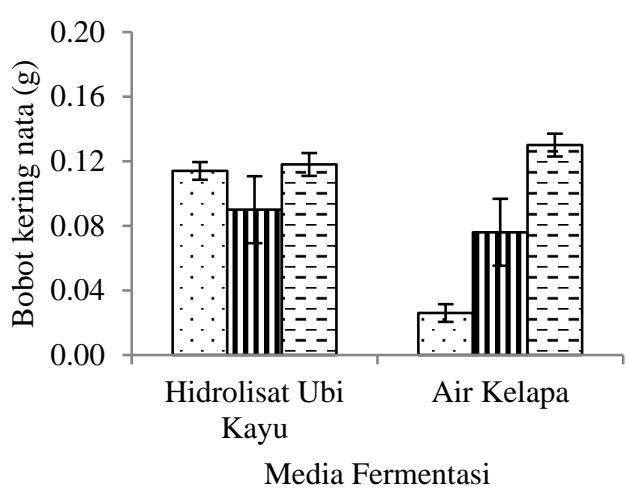

$\mathrm{E}$

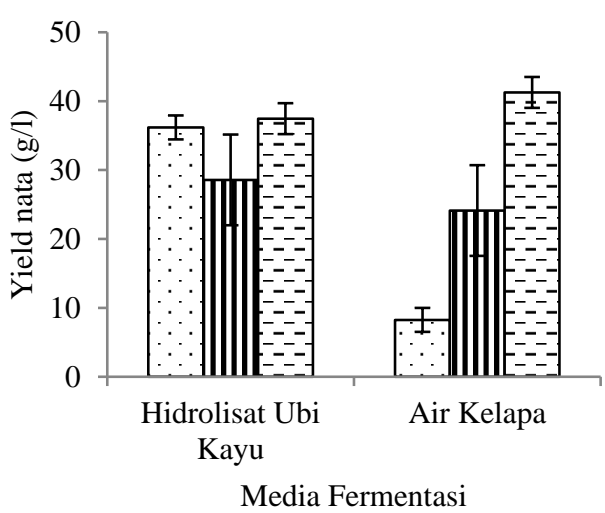

B

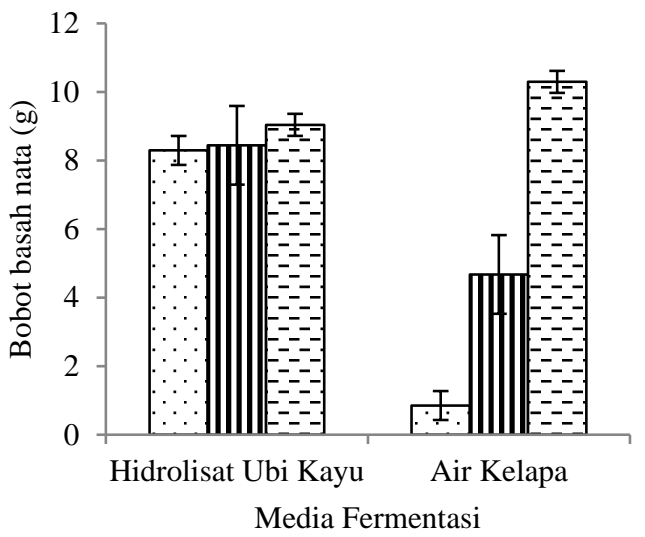

D

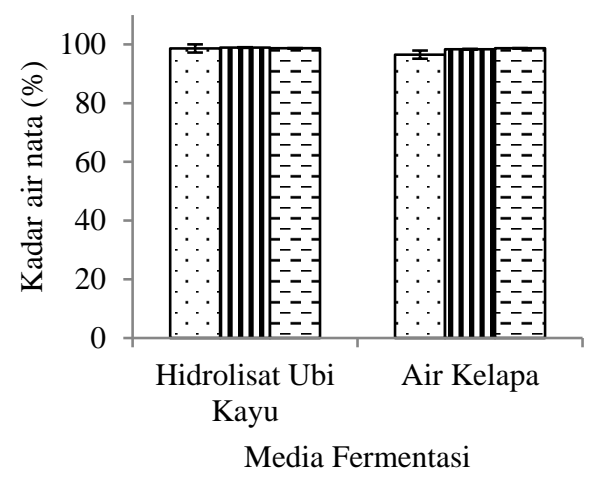

F

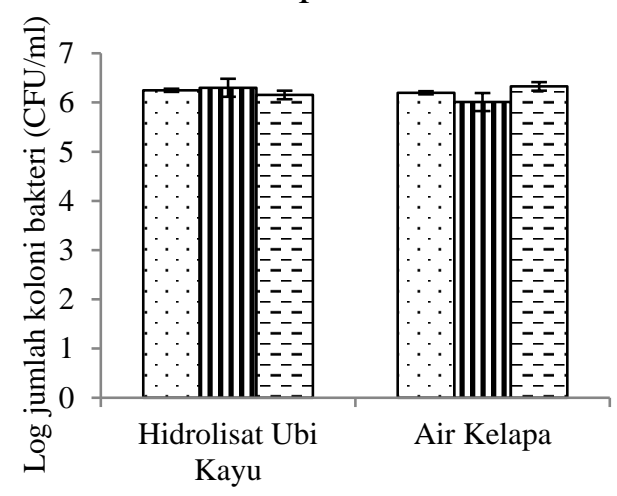

Media Fermentasi

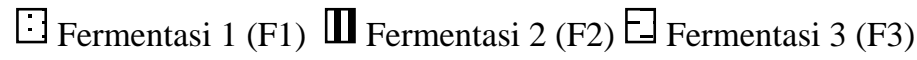

Gambar 4. Perbandingan rataan variabel kuantitatif nata pada media hidrolisat ubi kayu (U) dan media air kelapa (K) (A) ketebalan, (B) bobot basah, (C) bobot kering, (D) kadar air, (E) yield, dan (F) log jumlah koloni bakteri Gluconacetobacter sp. pada media HBA nata pada akhir fermentasi

Penambahan asam asetat pada media U memiliki peran positif bagi fermentasi nata. Menurut Vandamme et al. (1998) peran dari asam asetat adalah sebagai co-substrat penghasil ATP tambahan dari hasil oksidasi berupa air dan $\mathrm{CO}_{2}$ sehingga terjadi efisiensi dalam pemanfaatan gula pada sintesis selulosa. Katabolisme asam asetat dapat meningkatkan $\mathrm{pH}$ dan melawan penurunan $\mathrm{pH}$ akibat pembentukan asam (keto) glukonat, hal ini dapat dijadikan alasan kestabilan dari fermentasi media U. Menurut Saplaco dan Raymundo (1994), lima galur Acetobacter aceti subsp. Xylinum dapat 
menghasilkan nata yang stabil dengan karakteristik seperti kehalusan, kekokohan, dan ketebalannya dapat diterima selama tiga kali transfer berseri.

Pada fermentasi media K berdasarkan log jumlah koloni pada F2 dan F3 berbeda nyata koloni pada media $\mathrm{U}$ yang stabil. Hasil fermentasi media $\mathrm{K}$ mengalami perbaikan dari F1 hingga F3 hal ini dapat diasumsikan bahwa pada fermentasi media $\mathrm{K}$ ada dinamika pertumbuhan mikrob lain dan Gluconacetobacter sp. yang mempengaruhi kualitas nata, hal ini dapat dijelaskan oleh Seumahu et al. (2007) bahwa terdapat pertumbuhan bakteri-bakteri yang tidak ditambahkan pada saat awal inokulasi yang dianalisis dengan teknik ARDRA untuk mempelajari profil bakteri-bakteri yang terlibat pada fermentasi.

\section{Preferensi Jenis Gula oleh Gluconacetobacter sp. Selama Fermentasi}

Hasil pengujian gula dengan menggunakan HPLC sebelum dan sesudah fermentasi menunjukkan bahwa pada media U, kadar gula yang terdeteksi mengalami pengurangan yaitu glukosa dan fruktosa (Gambar 5A). Pengenceran hidrolisat menjadi 5\% dari hasil pengukuran brix, berdasarkan pengukuran HPLC dihasilkan total glukosa dan fruktosa antara 3,197-3,313\%. Berdasarkan penelitian Slominska et al. (2013), pada proses hidrolisis ubi kayu penambahan alfa amilase (likuifikasi) dan glukoamilase (sakarifikasi) dapat menghasilkan hidrolisat berupa glukosa, maltosa, maltotriosa. Pada penelitian ini, proses likuifikasi menggunakan alfa amilase Liquozyme ${ }^{\circledR}$ Supra. Dextrozyme DX digunakan untuk proses sakarifikasi karena terdapat glukoamilase dan pullulanase (Sunaryanto et al., 2013). Pada hasil HPLC media U

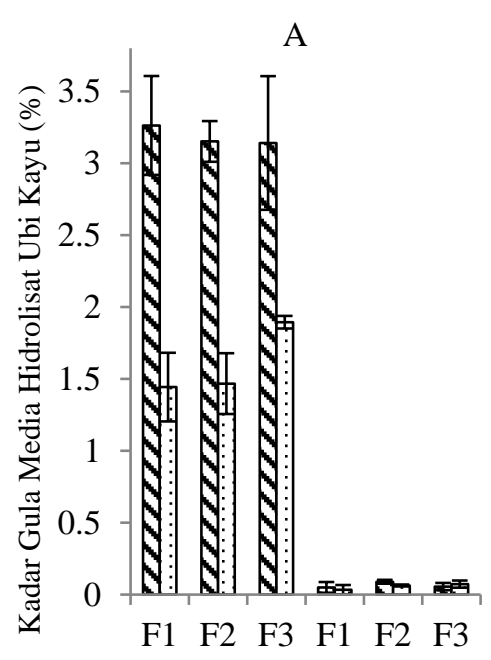

Glukosa Fruktosa baik sebelum dan setelah fermentasi yang memperlihatkan area puncak pada retensi waktu tertentu selain glukosa dan fruktosa . Pengaruh lama hidrolisis berpengaruh juga terhadap jumlah gula yang dihasilkan selama hidrolisis. Johnson et al. (2009) proses hidrolisis yang melibatkan Liquezyme-X dengan aktifitas $200 \mathrm{KNU} / \mathrm{g}$ dan Dextrozyme GA dengan aktifitas 270 amiloglukosidase (AG) /g dengan kondisi likufikasi pH 6,5, selama 1 jam dan suhu $90^{\circ} \mathrm{C}$ membutuhkan waktu sakarifikasi selama 48 jam pada kondisi $\mathrm{pH}$ 4,0 , suhu $60^{\circ} \mathrm{C}$ selama 48 jam menghasilkan $90,95 \%$ glukosa dari kondisi awal bubur ubi kayu $50 \%$ (w/v).

Sedangkan pada media $K$, gula yang terdeteksi antara lain sukrosa, glukosa, dan fruktosa (Gambar 5B). Total gula (glukosa, fruktosa, dan sukrosa) pada media $\mathrm{K}$ sebelum fermentasi adalah $3,571-6,058 \%$, bersifat fluktuatif dikarenakan adanya proses adaptasi dari Gluconacetobacter sp. terhadap media K. Pada media K penambahan Sukrosa sebanyak $2 \%$ saat pengaturan kadar gula total menjadi $5 \%$ ternyata mengalami perubahan menjadi lebih sedikit dari glukosa dan fruktosa, hal ini disebabkan akibat adanya proses sterilisasi media sehingga adanya pengaruh suhu dan asam asetat mengakibatkan sukrosa terhidrolisis menjadi glukosa dan fruktosa. Hasil pengujian anava untuk kadar sukrosa dan fruktosa sebelum dan sesudah fermentasi (F1, F2, F3) menunjukkan tidak ada perbedaan rataan yang signifikan antara kadar sukrosa dan fruktosa pada media $U$ dan kadar sukrosa media K selama fermentasi, kecuali kadar fruktosa media $\mathrm{K}$ yang berbeda signifikan pada taraf $5 \%$.

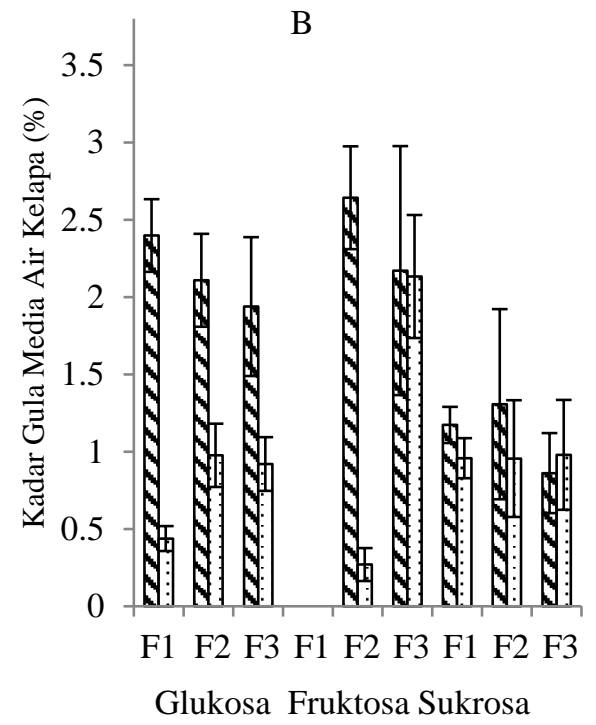

Sesudah fermentasi nata

Gambar 5. Kadar gula (glukosa, fruktosa, dan sukrosa) sebelum fermentasi nata dan sesudah fermentasi nata pada fermentasi 1 (F1), fermentasi 2 (F2), dan fermentasi 3 (F3) pada (A) media hidrolisat ubi kayu (U), (B) media air kelapa (K) 
Kadar glukosa selama fermentasi pada media $\mathrm{U}$ dan $\mathrm{K}$ menunjukkan hasil yang berbeda nyata terutama jelas terlihat pada media K (anava) pada taraf 5\% ini terlihat dari uji lanjut (Tukey) yang menunjukkan awal fermentasi berbeda dengan akhir fermentasi (F1, F2, F3). Media U menunjukkan perbedaan kadar glukosa selama fermentasi berdasarkan uji Kruskal Wallis

Hasil pengujian statistik pada fermentasi F1, F2, dan F3 menunjukkan preferensi Gluconacetobacter sp. terhadap glukosa lebih tinggi dibandingkan gula lainnya, ini menunjukkan bahwa glukosa memiliki peranan penting sebagai sumber karbon yang utama untuk produksi nata de coco. Pada media $\mathrm{K}$ penggunaan sukrosa menjadi alternatif terakhir untuk dikonsumsi bila dibandingkan dengan fruktosa, hal ini terlihat dari jumlah fruktosa yang berbeda pada awal dan akhir fermentasi yang dimungkinkan karena adanya metabolisme fruktosa oleh bakteri. Menurut Zhong et al. (2013) penggunaan sumber karbon campuran menunjukkan penggunaan glukosa 99\%, fruktosa $10 \%$ dan gliserol $85 \%$ sesudah 4 hari fermentasi oleh G. xylinus (CGMCC no. 2955). Menurut Toda et al. (1997) media yang mengandung sukrosa dengan penambahan asam asetat dapat menurunkan yield selulosa karena sistem transport sukrosa dihambat oleh asam asetat hal ini dapat dilihat pada inokulum air kelapa yang ditambahkan koloni bakteri yang tidak membentuk nata de coco.

Pengaruh Log Jumlah Koloni Gluconacetobacter sp. Terhadap Yield Nata dan Konsumsi Glukosa serta Pengaruh Konversi Glukosa dan Konsumsi Glukosa Terhadap yield Nata pada Media U Berdasarkan hasil uji regresi linier diketahui besarnya pengaruh beberapa faktor bebas (independen) terhadap faktor terikat (dependen) pada media $U$ yang besarnya dinyatakan dalam nilai koefisien determinasi $\left(R^{2}\right)$ (Tabel 1). Log jumlah koloni Gluconacetobacter sp. dan persentase konversi glukosa menjadi nata berpengaruh terhadap yield nata dengan nilai koefisien determinasi $71,70 \%$ dan $62,90 \%$. Konsumsi glukosa sangat dipengaruhi oleh log jumlah koloni Gluconacetobacter $\mathrm{sp} .\left(R^{2}=\right.$ $81,90 \%$ ), semakin banyak jumlah koloni bakteri maka jumlah glukosa yang dikonsumsi semakin banyak, hal ini ditunjukkan dengan nilai koefisien regresi 0,905 yang artinya korelasi antara kedua variabel sangat kuat. Akan tetapi, persentase konsumsi glukosa tidak terlalu berpengaruh terhadap yield nata $\left(R^{2}=29,20 \%\right)$, hal ini dapat menjelaskan bahwa terdapat faktor lain yang dapat mempengaruhi pembentukan nata selain jumlah glukosa yang dikonsumsi oleh bakteri. Yield nata pada media U memiliki korelasi yang kuat dengan konversi glukosa menjadi nata $(R=0,793)$, semakin tinggi glukosa yang dikonversi menjadi nata oleh mikrob, maka yield nata semakin meningkat dengan koefisien determinasi $62,90 \%$ yang menandakan konversi glukosa menjdi nata berkaitan dengan yield nata.

Faktor lain yang dapat berpengaruh terhadap yield nata adalah nutrisi yang terdapat pada hidrolisat ubi kayu. Menurut USDA (2016) jenis nutrisi yang terdapat di dalam ubi kayu terdapat kesamaan dengan yang terdapat di dalam air kelapa, seperti proksimat berupa protein, karbohidrat, gula dan mineral berupa kalsium $(\mathrm{Ca})$, besi $(\mathrm{Fe})$, magnesium $(\mathrm{Mg})$, fosfor $(\mathrm{P})$, kalium $(\mathrm{K})$, natrium (Na) serta vitamin berupa niasin dan asam askorbat (Vitamin C) memiliki fungsi dalam pembentukan nata. Unsur seperti $\mathrm{Na}, \mathrm{K}, \mathrm{Ca}, \mathrm{Mg}$ dan $\mathrm{Fe}$ adalah nutrisi yang memainkan peranan penting dalam produksi selulosa oleh bakteri, karena merupakan kofaktor enzim dalam produksi seperti polisakarida (Martins et al., 1990; Wong, 1993). Dalam produksi selulosa bakteri Acetobacter sp. A9, magnesium penting untuk menjaga metabolisme sel. Unsur ini juga penting untuk pertumbuhan dan produksi selulosa (Son et al., 2001), karena berperan secara langsung dalam aktifitas enzim selulosa sintase, yang diaktifkan oleh oligonukleotida guanil (Ross et al., 1986; Fontana et al., 1997) dan penting dalam proses menghubungkan antara subunit mikrofibril (Saxena dan Brown, 2001). Penambahan media sintesis atau alami (air kelapa) yang mengandung glukosa, mineral yang memiliki unsur $\mathrm{N}, \mathrm{S}, \mathrm{K}, \mathrm{P}$, $\mathrm{Na}, \mathrm{Mg}, \mathrm{Fe}, \mathrm{B}$ serta nikotinamida dan etanol menghasilkan selulosa dengan yield yang besar (Son et al., 2003; Almeida et al., 2013). Menurut Keshk (2014) vitamin C berfungsi sebagai antioksidan yang dapat meningkatkan produksi selulosa dengan cara mengurangi konsentrasi asam glukonat, sehingga kandungan vitamin $\mathrm{C}$ pada ubi kayu sangat bermanfaat untuk pembentukan nata.

Tabel 1. Regresi dan korelasi beberapa variabel pada media U

\begin{tabular}{|c|c|c|c|}
\hline \multicolumn{2}{|c|}{ Pengaruh faktor bebas terhadap faktor terikat } & \multirow{2}{*}{$\begin{array}{c}\text { Koefisien } \\
\text { regresi }(R)\end{array}$} & \multirow{2}{*}{$\begin{array}{c}\text { Koefisien } \\
\text { determinasi }\left(R^{2}\right)\end{array}$} \\
\hline Variabel bebas & Variabel terikat & & \\
\hline Log jumlah koloni Gluconacetobacter sp. & yield nata & $-0,847$ & $71,70 \%$ \\
\hline Log jumlah koloni Gluconacetobacter sp. & konsumsi glukosa & 0,905 & $81,90 \%$ \\
\hline Konsumsi glukosa & yield nata & $-0,540$ & $29,20 \%$ \\
\hline Konversi glukosa menjadi nata & yield nata & 0,793 & $62,90 \%$ \\
\hline
\end{tabular}




\section{KESIMPULAN DAN SARAN}

\section{Kesimpulan}

Media hidrolisat ubi kayu dapat digunakan sebagai media untuk membuat inokulum fermentasi atau media produksi nata de coco karena selain tidak perlu penambahan gula, dinamika pertumbuhan bakterinya relatif stabil pada media tersebut.

Nata de coco dengan inokulum Gluconacetobacter sp. pada media hidrolisat ubi kayu menghasilkan produk yang konsisten yang dapat dilihat dari hasil pengamatan kuantitatif. Hasil pengamatan kuantitatif yang mudah diamati adalah ketebalan natanya yang relatif stabil bila dibandingkan media air kelapa. Bakteri tersebut menggunakan glukosa sebagai sumber utama fermentasi nata.

\section{Saran}

Untuk meningkatkan potensi aplikasi pada industri perlu dilakukan pengujian lanjutan optimasi media hidrolisat ubi kayu, besarnya pengaruh nutrisi hidrolisat dan perubahan $\mathrm{pH}$ selama fermentasi serta pembentukan komunitas mikroba pada inokulum.

\section{UCAPAN TERIMA KASIH}

Penulis mengucapkan terima kasih kepada Kemenristek Dikti yang telah memberikan dana penelitian, Balai Besar Teknologi Pati, Badan Pengkajian dan Penerapan Teknologi (B2TP, BPPT) yang membantu dalam pengujian serta PT Niramas Utama yang memberikan kesempatan untuk menggunakan laboratoriumnya untuk penelitian.

\section{DAFTAR PUSTAKA}

Afreen SS dan Lokeshappa B. 2014. Production of bacterial cellulose from Acetobacter Xylinum using fruits wastes as substrate. International Journal Science Technology. 2(8): 57-64.

Almeida DM, Prestes RA, Fonseca AFD, Woiciechowski AL, Wosiacki G. 2013. Minerals consumption by Acetobacter xylinum on cultivation medium on coconut water. Brazilian Journal Microbiology. 44(1): 197-206.

Arnata IW. 2009. Pengembangan alternatif teknologi bioproses pembuatan bioetanol dari ubi kayu menggunakan Trichoderma viride, Aspergillus niger dan Saccharomyces cerevisiae [tesis]. Bogor (ID): Institut Pertanian Bogor.

Ayoola AA, Adeeyo AO, Efeovbokhan CV, Olasimbo DA. 2013. Optimum hydrolysis conditions of cassava starch for glucose production. IJARIE. 2(1): 93-101.

Barus T. 2008. Peran komunitas bakteri dalam pembentukan rasa pahit pada tempe: analisis mikrobiologi dan Terminal Restriction
Fragment Length Polymorphism (T-RFLP) [Disertasi]. Bogor (ID): Sekolah Pascasarjana Institut Pertanian Bogor.

Collares RM dan Miklasevicius LVS , Bassaco MM, Salau NPG, Mazutti MA, Bisognin DA, Terra LM. 2012. Optimization of enzymatic hydrolysis of cassava to obtain fermentable sugars. Journal Zhejiang Univ-Sci B (Biomed Biotechnol). 13(7):579-586.

Dawson EH dan Harris BL. 1951. Sensory Methods for Measuring Differences in Food Quality Review of Literature and Proceedings of Conference. Washington DC. (US): U.S. Gov Printing Office.

Efriwati. 2013. Dinamika populasi bakteri asam laktat (BAL) dan khamir selama produksi tempe [Disertasi]. Bogor (ID): Institut Pertanian Bogor.

Farid MA, Shata HM, Noor El-Deen AM, Abdelwahed NA. 2015. Semisolid state fermentation: effects of beet sugar root : peptone ratio on erythromycin production by Saccharopolyspora erythraea NCIMB 12462. Egypt Pharmaceut J .14:94-102.

Fontana JD, Joerke CG, Baron M, Marashchin M, Ferreira AG, Torriani I, Souza AM, Soares MB, Fontana MA, Guimaraes MF. 1997. Acetobacter cellulosic biofilms search for new modulators of cellulogenesis and native membrane treatments. Appl Biochem Biotechnol. 63:327-338.

Hungund BS dan Gupta SG. 2010. Strain improvement of Gluconacetobacter xylinus NCIM 2526 for bacterial cellulose production. African Journal Biotechnol. 9(32): 5170-5172.

Jagannath A, Kalaiselvan A Manjunatha SS, Raju PS, Bawa AS. 2008. The effect of $\mathrm{pH}$, sucrose and ammonium sulphate concentrations on the production of bacterial cellulose (Nata-de-coco) by Acetobacter xylinum. World Journal Microbiol Biotechnol. 24:2593-2599.

Johnson R, Padmaja G, dan Moorthy SN. 2009. Comparative production of glucose and high fructose syrup from cassava and sweet potato roots by direct conversion techniques. IFSET.10: 616-619

Juara SR. 2011. Detoksifikasi hidrolisis asam dari ubi kayu dengan metode arang aktif untuk produksi bioetanol [tesis]. Bogor (ID): Institut Pertanian Bogor.

Keshk SMAS dan Sameshima K. 2005. Evaluation of different carbon sources for bacterial cellulose production. Africa Journal Biotechnol. 4(6):478-482.

Keshk SMAS. 2014. Vitamin C enhances bacterial cellulose production in Gluconacetobacter xylinus [komunikasi singkat]. Carbo Polym. 
99: 98- 100.DOI:10.1016/j.carbpol.2013. 08.060 .

Kurosumi A, Sasaki C, Yamashita Y, Nakamura Y. 2009. Utilization of various fruit juices as carbon source for production of bacterial cellulose by Acetobacter xylinum NBRC 13693. Carbo Polym. 76: 333-335.

Lebot V. 2009. Tropical Root and Tuber Crops Cassava, Sweet Potato, Yams and Aroids. Oxfordshire (GB): CABI.

Lestari P, Elfrida, Suryani A, Suryadi Y. 2014. Study on the production of bacterial cellulose from Acetobacter xylinum using agro-waste [komunikasi singkat]. Jor Journal Bio Sci. 7: 75-80.

Li BW. 1996. Determination of sugars, starches, and total dietary fiber in selected highconsumption foods [abstrak]. Journal AOAC International. 79(3):718-23.

Maharani DM. 2011. Adaptasi Saccharomyces cerevisiae terhadap hidrolisis asam ubi kayu untuk produksi bioetanol [tesis]. Bogor (ID): Institut Pertanian Bogor.

Martins LO, Brito LC, Sá-Correia I. 1990. Roles of $\mathrm{Mn}^{2+}, \mathrm{Mg}^{2+}$ and $\mathrm{Ca}^{2+}$ on alginate biosynthesis by Pseudomonasaeruginosa. Enz Microbial Technol. 12:794-799.

Naufalin R dan Wibowo C. 2004. Pemanfaatan hasil samping pengolahan tepung tapioka untuk pembuatan nata de cassava: kajian penambahan sukrosa dan ekstrak kecambah. Jurnal Teknologi Industri Pangan. 15 (2): 153-158.

Nazir AHBM. 2012. Optimization of bacterial cellulose production in apple juice medium by using response surface methodology (RSM) [tesis]. Pahang (MY): Universiti Malaysia Pahang.

Neviani E, Bottari B, Lazzi C, Gatti M. 2013. New developments in the study of the microbiota of raw-milk, long-ripened cheeses by molecular methods: the case of Grana Padano and Parmigiano Reggiano [ulasan]. Frontiers Microbiol. 4 (36): 1-14.

[Niramas] PT Niramas Utama. 2012. INACO pelopor jajanan sehat berbasis kelapa. Karya Indonesia. Made In Indonesia: 1 (hlm 22-23) [Internet]. [diunduh 2015 Nov 22]. Tersedia pada: http://www.kemenperin.go.id/ download/2815\%20Cach ed\%20Similar.

Ross P, Aloni Y, Weinhouse H, Michaeli D, Weinberger-Ohana P, Mayer R, Benziman M. 1986. Control of cellulose synthesis in Acetobacter xylinum. A unique guanil oligonucleotide is the activator of the cellulose synthetase. Carbohy Res. 149:101117.

Ruiz MI, Sanchez CI, Torres RG, Molina DR. 2011. Enzymatic hydrolysis of cassava starch for production of bioethanol with a colombian wild yeast strain. Journal Brazilian Chemical Soc. 22(12): 2337-2343.

Sanchez PC. 2008. Philippine Fermented Foods Principles and Technology. Quezon City (PH): Univ Philippines Pr.

Saplaco SR dan Raymundo AK. 1994. Stability of Acetobacter aceti subsp. Xylinum, the nata de coco producer [abstrak]. Phil J Biotechnol.

Saxena IM dan Brown Jr RM. 2001. Structurefunction characterization of cellulose synthase: Relationship to other glycosyltransferase. Phytochem. 57:11351148.

Seumahu CA, Suwanto A, Hadisusanto D, Suhartono MT. 2007. The dynamics of bacterial communities during traditional nata de coco fermentation. Jurnal Mikrobiol Indonesia. 1(2): 65-68.

Seumahu CA, Suwanto A, Rusmana I, Solihin DD. 2013. Bacterial and fungal communities in tempeh as reveal by amplified ribosomal intergenic sequence analysis. Hayati Jurnal Biosci. 19(2): 65-71.

Słomińska L, Zielonka R, dan Jarosławski L. 2013. The unconventional single stage hydrolysis of potato starch. Pol Journal Chem Tech. 15(3): 7-14.

Soebrata BM, Mulijani S, dan Sane CDS. 2012. Nata de cassava dari limbah cair tapioka sebagai membran selulosa asetat. Di dalam: Dahlan $\mathrm{K}$ et al., editor. Prosiding Seminar Nasional Sains V" Sains Sebagai Landasan Inovasi dalam Bidang Energi, Lingkungan dan Pertanian Berkelanjutan"; 2012 Nov 10; Bogor, Indonesia. Bogor (ID): FMIPA-IPB . hlm 845-854.

Son HJ, Heo MS, Kim YG, Lee SJ. 2001. Optimization of fermentation conditions for the production of bacterial cellulose by a newly isolated Acetobacter sp. A9 in shaking cultures. Biotechnol Appl Biochem. 33: $1-5$.

Son HJ, Kim, HG, Kim KK, Kim HS, Kim YG, Lee SJ. 2003. Increased production of bacterial cellulose by Acetobacter sp. V6 in synthetic media under shaking culture conditions. Biores Technol. 86:215-219.

Sunaryanto R, Handayani BH, dan Safitri R. 2013. Enzymatic and acid hydrolysis of sago starch for preparation of ethanol production. Microbiol Indonesia. 7(2): 68-74. DOI: 10.5454/mi.7.2.4.

Toda K, Asakura T, Fukaya M, Entani E, Kawamura Y. 1997. Cellulose production by acetic acid-resistant Acetobacter xylinum. Journal Fermen Bioeng. 84 (3): 228-231.

[USDA] United States Department of Agriculture. 2016. Agricultural research service. National Nutrient Database for Standar Reference 
Release 28 [Internet]. [diunduh 2016 Feb 27]. Tersedia pada: https://ndb.nal.usda.gov/ndb/foods/show/366 5 ? $\mathrm{manu}=\& \mathrm{fgcd}=$.

Vandamme EJ, De Baets S, Vanbaelen A, Joris K, De Wulf P. 1998. Improved production of bacterial cellulose and its application potential. Polym Degrad Stabil. 59: 93-99.

Wong TY. 1993. Effects of calcium on sugar transport in Azotobacter vinelandii. Appl Environ Microbiol. 59:89-92.

Yamada Y dan Yukphan P. 2008. Genera and species in acetic acid bacteria. International Journal Food Microbiol. 125: 15-24.
Zakaria J dan Nazeri MA. 2012. Optimization of bacterial cellulose production from pineapple waste: effect of temperature, $\mathrm{pH}$ and concentration. 5th Engineering Conference, "Engineering Towards Change - Empowering Green Solutions"; 2012 Jul 10-12; Kuching Sarawak, Malaysia. Kuching (MY): Universiti Malaysia Pahang.

Zhong C, Zhang GC, Liu M, Zheng XT, Han PP, Jia SR. 2013. Metabolic flux analysis of Gluconacetobacter xylinus for bacterial cellulose production. Appl Microbiol Biotechnol. DOI: 10.1007/s00253-013-49088. 